\title{
Hydropower and sustainable development: a case study of Lao PDR
}

\author{
S. Jusi \\ Finland Futures Research Centre, Turku School of Economics, Finland
}

\begin{abstract}
Lao People's Democratic Republic (PDR) has large hydro-power potential with estimates varying from $18,000 \mathrm{MW}$ to $30,000 \mathrm{MW}$, out of which only two percent $(667,5 \mathrm{MW})$ has been developed so far. Despite the fact that the hydropower sector has played a pivotal role in the economic development of Lao PDR, planning, selection and implementation processes for hydropower projects have tended to be ad hoc in character, have experienced insufficient transparency and have not delivered the full potential benefits to the development of the country. Whereas substantial improvements in policies, legal requirements and assessment guidelines have occurred, hydropower planning and development still need a lot of improvement. Some major problems relate to capacity and institutional environment, such as insufficient quality of environmental and social assessments, ineffective regulatory framework, a lack of transparency, and the failure to conduct comprehensive consultations with all stakeholders.

Hydropower development in Lao PDR and in the whole Mekong Region needs to be sustainable, which will require minimal adverse social and environmental impacts, while remaining a viable, profitable and source of renewable energy supporting the country's economic development. Hydropower development should also better respond to the realities of regional energy market. Hydropower must be developed cautiously in the context of broader development goals, including responsible environmental management, institutional development, poverty alleviation and social development along with integrated water and energy management. Sustainable development of hydropower requires the integration of economic and social development and environmental protection and the need to take into account the values of efficiency, participatory decision-making, sustainability, accountability along with precautionary approach to environmental management and eco-efficiency. The purpose of the paper is to identify key challenges related to sustainable hydropower planning and development in Lao PDR. The paper aims to
\end{abstract}


contribute to the broader discourse on sustainable hydropower planning and development in developing countries.

Keywords: hydropower, Lao PDR, sustainable, development, planning, risks.

\section{Introduction and background}

Management of water resources in an effective, efficient, equitable and sustainable manner will be essential for ongoing national level. The national objectives of the hydropower development are to expand an affordable, reliable and sustainable electricity supply, to promote economic and social development and to overcome Lao PDR's comparative disadvantages in attracting industry and investment $[29,43]$. The Government of Lao PDR (GOL) has committed itself to increasing electrification to 90 percent by 2020 [29, 35]. Hydropower generation is also an opportunity for the country to contribute to international efforts to reduce greenhouse emissions.

There are high potentials of electricity that can be generated from about six to eight small dams, which are capable of generating 600-800 MW [36]. The construction of some other major power plants/projects as part of the five-year plan has commenced, including the Nam Theun 2 Hydropower Project, which will add another 1,070 MW capacity by the end of 2009. The GOL has to date signed MOUs or is undertaking research studies on a total of more than 70 hydropower projects [11]. On average 65 to 80 percent of the annually produced energy is exported [48].

The amount of power imported is expected to grow as a result of the rapidly increasing demand and the constraints on power generation [33]. Currently, domestic energy consumption is growing at eight to ten percent annually [48]. Until the year 2020, the electricity demand forecast is 7,770.7 GWh (average growth rate is $13 \%$ per year) and peak load is $1,486.8 \mathrm{MW}$ (average growth rate is $11 \%$ per year) [12]. Due to its energy surplus and geographical location at the hub of the Greater Mekong Sub-region, the Lao PDR is strategically positioned to play a significant role in promoting regional power trade $[29,31,44]$.

Currently the Lower Mekong Basin (LMB) countries are net importers of fossil fuels, therefore hydropower projects would bring significant macroeconomic benefits by reducing dependency on energy imports from outside the region. Measures to combat climate change may also be expected to include a greater dependence on hydropower as a renewable source of electricity and raises a major sustainability issue of global importance [8]. The issue of climate change and hydropower is important one but not discussed here due to limitation of space (see more for example [1-3, 10, 21, 46]).

Hydropower investment decisions by the public and private sectors alike have been made on an individual project basis without reference to any plan to ensure that the priority and scope of projects are consistent with optimal development objectives. When developed appropriately, with attention to social and environmental risks, hydropower projects can provide multiple economic and environmental benefits to the poor people of Lao PDR. The literature on sustainable approach in hydropower development $[26,46,47]$ emphasizes the 
importance of different aspects of sustainability in the successful implementation of the sustainable approach. These aspects are social, economic and environmental sustainability together with precautionary and eco-efficiency approaches. The key question to consider is how to provide energy in a way that is consistent with the goals and principles of sustainable development, ensuring a better quality of life for all people, including future generations [30].

This paper is not intended to be a comprehensive analysis, but rather a 'discussion startup' that will help steer both hydropower/energy and environment decision-makers as well as future work to strengthen the sustainable and sound environmental, social and economic development of Lao PDR.

\section{Hydropower and sustainable development context}

Hydropower has been perceived and promoted as a comparatively clean, lowcost, renewable source of energy that relies on proven technology [46]. Except for reservoir evaporation, which makes the hydropower to have a big water footprint [17] it is a non-consumptive use of water. At the same time, the hydropower can also be viewed as large 'ecological footprint' sectors - that is, it has substantial impacts on the natural environment because of its use and reliance upon natural resources [10]. Also, classified as a clean, renewable energy source, hydropower can reduce the net production of greenhouse gases by moving economies to a lower-carbon future by displacing other forms of power generation $[20,47]$.

There are risks inherent in the development and operation of hydropower. These risks cross the range of financial, engineering, geological, and market concerns, with particular attention to environmental protection, social inclusion, resettlement and sharing of the benefits of development across all stakeholders. Hydropower reservoirs have a large number of potential cross-sectoral impacts, including changes in downstream flows and water quality, dam safety, in-stream and reservoir fisheries, resettlement, ecological impacts, and flood control [10, $19,44,46]$. As a consequence of a wide variety of impacts and risks, the definition of acceptable hydropower has shifted to one that recognizes the core principles of sustainable development, with attention to social, environmental and economic aspects $[8,27,47,50]$.

\subsection{Sustainable development}

The Brundtland Commission has defined sustainable development as being development that meets the needs of the present without compromising the ability of future generations to meet their own needs [40]. Sustainable development requires the integration of three components - economic development, social development and environmental protection - as interdependent, mutually reinforcing pillars. Eradicating poverty, changing unsustainable patterns of production and consumption, and protecting and managing the natural resource base underpinning economic and social 
development are overarching objectives of, and essential requirements for sustainable development [50].

International organizations like the International Hydropower Association [27] and World Commission on Dams [46] among the international financiers [47] have produced guidelines to promote greater consideration of environmental, social and economic aspects in the sustainability assessment of hydro projects and the management and operation of existing power schemes. While there is disagreement on some aspects relating to WCD's detailed recommendations, there is clear acceptance of the core values listed in the report, which are equity, efficiency, participatory decision-making, sustainability, and accountability [27].

Also the values of precautionary approach and eco-efficiency to environmental management have been supported in developing sustainable hydropower. The precautionary principle and the principle that preventive action should be taken can guide hydropower decision-making and planning in the face of risk and uncertainty of the total impact of the hydropower development (see more $[22,42,46])$. In the case of the precautionary principle reference is made to the Rio declaration on Environment and Development (Rio Declaration, 1992), where it is stated that: Where there are threats of serious or irreversible environmental damage, the lack of full scientific certainty shall not be used as a reason for postponing cost effective measures to prevent environmental degradation. This statement may be extended to any risk, such an economic, ecological or social risks [16]. IHA [27] believes evaluation of power generation options should be based, where feasible, on life-cycle analysis of alternative technologies with a precautionary approach to scientific uncertainties.

Eco-efficiency is founded on the idea - doing more with less - is at the core of the business case for sustainable development. Combining environmental and economic operational excellence to deliver goods and services with lower external impacts and higher quality-of-life benefits is a key sustainable development strategy for business (see more [28, 49, 50]).

At the domestic level, good governance with sound environmental, social and economic policies, together with democratic institutions responsive to the needs of people, the rule of law, anticorruption measures, gender equity and an enabling environment for investment are the basis for sustainable development [50]. Sustainability is based on due considerations given to interrelationships and integration of competing needs. Therefore, it is of prime importance that the national and/or regional policy context takes into account cross-sectoral issues, for example through integrated water resources management (IWRM) [50].

Hydropower development must adopt the dual perspective of integrated water resources management and energy development that takes into account the broad range of social, economic, and environmental issues [47]. IWRM is about strengthening frameworks for water governance to foster good decision-making in response to changing needs and situations. Here, the rather universal definition of IWRM "as a process that promotes the coordinated development and management of water, land and related resources in order to maximize the resultant economic and social welfare in an equitable manner without 
compromising the sustainability of vital ecosystems" defined by GWP [18] is used (see also [8, 26, 42, 46]). Such decision support systems as IWRM appear particularly appropriate and useful in hydropower development when implemented within a participatory, transparent multi-stakeholder approach [16, 46].

\section{Sustainability in the hydropower sector in Lao PDR}

\subsection{Environmental and social aspects of sustainability}

It is important to ensure that hydropower potential in Lao PDR will be sustainably developed, which implies achieving minimal adverse social and environmental impacts, while remaining a viable, profitable and source of renewable energy supporting the country's economic development. The selection, design, construction and operation of hydropower projects need to take into account the environmental and social impacts in a manner sympathetic to the environment and society. The Government is committed to reducing dependence on fuel wood and imported fossil fuels by promoting, where practicable, renewable forms of electrical energy, especially the hydropower projects [44]. As rural Lao remains an essentially agrarian society, and the livelihoods of its people are underpinned by the presence of the healthy and diverse ecosystems that provide them with sustenance, the issue of sustainability is an important one [5].

The Government of Lao has already developed quite a comprehensive body of domestic legislation; the Law on Water and Water Resources (1996), Forestry Law (1996), Land Law (1997), Agriculture Law (1998), and Environmental Protection Law (1999) to deal with sustainability and environmental conservation issues in its policies and regulations to ensure sustainable development [48].

According to the Environmental Protection Law of 1999, and Environmental Assessment Regulations 1770 of 2000, all large hydropower projects must produce a full Environmental Impact Assessment (EIA) report and Environmental Management Plan (EMP) [39]. The Electricity Law (1997) stipulates that investors in electricity production have the obligation to protect the environment, namely to assess the impact on natural environment, on the ecosystem, to limit the impact on society and wildlife habitat [44]. Moreover, recently enacted Lao Technical Electric Standard provides all the necessaries guidance to maximize dam safety during construction and operation [24]. The Lao EIA process is largely compatible with international guidelines for conducting EIAs and the bottom line is that construction activities cannot commence until the Water Resources and Environment Agency (WREA) approval is received [10]. The social and environmental safeguards of the Multilateral Development Banks have enhanced the implementation processes of many hydropower developmental projects in Lao PDR, which lack human, technical and financial resources. 
With regard to the coming Nam Theun 2, a lot has been learnt from previous experiences and issues like environmental impact and resettlement have been thought over and revised in project preparation [4]. One important policy to arise from the project has been the GOL's National Policy: Environmental and Social Sustainability of the Hydropower Sector in Lao PDR. The aim of this policy is to help ensure that the principles of social and ecological sustainability are integrated into all large hydropower developments. [39]. The establishment of the first Watershed Management Protection Authority in Lao PDR is also an accomplishment of the Nam Theun 2. This Authority is responsible for the management and protection of the watershed of the Nam Theun 2 above the reservoir formed by the Nam Theun 2 hydro-electric dam [34]. The Environmental Protection Fund (EPF) has now been established, with a specialized funding 'windows' for the collection, management and distribution of funds from large scale water developers such as hydropower [13]. However, the fund has not been functioning properly [41]. Additionally, an integrated approach to river basin management will be practiced for multiple projects planned to dam a single river [7].

Major gaps remain, however, between the formulation and implementation of legal instruments, and between the establishment and enforcement of rules and regulations. Capacity for implementation is still lacking. EIA still frequently fails to influence decision-making, like for example the case of Theun-Hinboun dam shows [5, 10, 27, 46]. Additionally, inadequate transparency and poor accountability compromise the ability to monitor the environment $[6,10]$. Despite rather wide range of IWRM capacity building steps, much more remains to be done. The legal and financial basis of IWRM is still rather limited with lack of coordination and efficiency [7].

Currently there is no national water resource information management system and water related data is fragmented and scattered among agencies. Access to data and other issues are major constraints to the development of the water sector policies and strategies, as well as water resource project and to integrated water resources management $[7,45]$.

Public hearings in hydropower development are an essential safeguard mechanism for a meaningful intervention by consumers and other vulnerable stakeholders in decisions that will ultimately become their lasting economic and social burden [19, 46]. Citizens need to have right to question and oppose new dam construction, and have their concerns addressed in all phases of planning, construction and operation. Critics are concerned with lack of public participation in Lao PDR and that corruption and lack of democracy in Mekong countries will be increased rather than decreased by revenue streams from large hydropower projects [19].

When planning and developing hydropower sector investment, on-going development of the legal, institutional and regulatory environment and strengthening of the institutional capacity and improvements in the commercial position of Electricite du Laos (EDL) are issues to be considered in Lao PDR $[15,29]$. Applying environmental considerations in the early stages of hydropower sector planning is necessary for improving the economic benefits of 
hydropower development and reducing subsequent project preparation time [8]. Applying sustainability considerations promotes a recognition of the strong linkage between environmental and social impacts of hydropower projects. Identifying potential social impacts at preliminary project scoping stages will facilitate consideration of alternative design options and viable livelihood development programs through a more participatory approach by avoiding the time pressures associated with the latter stages of project appraisal process and financial closure [8].

\subsection{Economic aspects of sustainability}

There can be no sustainable development without the demonstration of sound and equitable distribution of economic benefits. For this reason economic considerations are a central in the decision-making processes associated with hydropower projects. The efficient use of economic resources requires that the best options are selected, that alternatives have been carefully evaluated, and that there are no hidden and unforeseen costs that could emerge in the future [38].

Demand growth has been rapid and the availability of concessional funds and grants is not keeping pace with the increasing capital requirements of the sector. Recently, restructuring and reform of the energy and water sector in many countries including Lao PDR has changed the role of government in decisionmaking and planning, with private investors and corporations taking both financing and ownership roles in these projects [46]. Moreover, the improvement in EDL's financial position is encouraging private investors and lenders to consider national supply as well as export markets [29]. The capital and resource requirements of large export power projects require private sector participation which the Government mobilizes using Build-Operate-Transfer (BOT) modalities [44].

The financing vacuum left by the withdrawal of the development agencies has been filled for the moment by non-traditional sources of finance, notably the China Exim Bank in Lao PDR. Finance from these sources appears to be abundant and the financing model is effective in accessing loans, but it is new and the associated procurement practices are weak. [29]. NGOs and IFIs alike have raised concerns that Chinese hydropower financiers and developers generally lack policies on environmental and social issues and do not necessarily adhere to internationally accepted standards and guidelines [37, 46]. Moreover, it is difficult for policy-makers to keep pace with the scale of investment and economic growth in Lao PDR.

There are many other weaknesses in private financing models which may impact negatively to economic sustainability and effectiveness in Lao PDR. Promotion of Independent Power Producer (IPP) projects in Lao PDR begins with an unsolicited proposal from a sponsor and, from this, an MOU is drawn up and a concession ultimately negotiated. Concessions are awarded in the absence of competition after the sponsor has completed technical and environmental studies of the proposed project. [29]. Moreover, the involvement of the private sector on a significant scale introduces problems for power planners in managing the uncertainty of IPP commercial operation date (COD) and a means of 
countering this risk must be found for the private sector's role in domestic generation development to be dependable and constructive [29]. Delays in CODs lead to increases in interest accumulated on funds borrowed for construction activities and to delays in revenues accruing to the owner from the completed project [46].

Overall, the failure of project delivery (IPP) can be seen as one of problems related to the practice of awarding mandates for IPP projects as an unsolicited, negotiated transaction based on a BOT modality. Problems related to this approach include the lack of transparency and competition, the failure to filter out projects inconsistent with IPP program objectives, a high degree of uncertainty on project outcomes, insufficient government control of project development, and unnecessary time commitments for all parties in Lao PDR [29, 51].

When it comes to future plans for hydropower projects in the region and in Lao PDR, they are justified in part by uncertain projections of high demand for electricity in Thailand, Vietnam and China [19]. This has implicated overstating export prospects in Lao PDR. It has also been criticized that the future power targets of the EDL's Power Development Plan (2007-16) are not achievable due to lack of availability of funds for capital works and, secondly, capacity constraints within the Lao power transmission and distribution system [29].

Overstating future demand has led to a perceived need for a large incremental response to meet rapidly growing needs. In many circumstances this has militated against a gradual approach of adopting smaller, non-structural options and has pushed decision-makers into adopting large-scale dam projects because they seem to be the only adequate response to the large gap between existing supply and forecast demand. Of principal concern is that it is frequently the agencies (like in Thailand) that are responsible for building supply infrastructure that are also charged with undertaking demand forecasts, leading to a potential conflict of interest $[14,19,46]$.

The opening of the sector to new financing models is fundamentally changing the way in which projects are planned and implemented. Developing new financial models require strong independent regulation and integrated resource planning [19]. There is a need to establish a regulator to set domestic retail tariffs and negotiate wholesale export tariffs. This would mean tariffs could be pre-set before bidding power generation concessions and bidding would therefore be on some other criterion, perhaps the highest royalty payments. Also, a creation of a centralized Lao power purchasing agency that could competitively bid power concessions within Lao PDR and could sell the off-take from some or all Lao projects to domestic and/or foreign power purchasers is needed [29].

Increase of the efficiency of energy use and the use of renewable sources is a priority for achieving a sustainable and equitable energy sector [46]. Lao PDR has yet very little experience implementing energy savings programs. Subsidies should be removed and, and hydropower should be forced to compete on a fair, least economic cost basis with a broad range of cleaner and less expensive alternatives [19]. 


\section{Concluding remarks}

The country's abundant water resources and mountainous terrain have allowed the Government of Lao to set up a master plan to develop hydropower and export large quantities of hydroelectric energy. The opportunities and challenges of hydropower development are complex, and ultimately dependent on the resources, skills, and will to invest responsibly, with due regard to economic, environmental and social aspects of sustainable development.

Emerging trends, driven by more sophisticated energy markets, volatile energy prices, climate change, and increased attention to water management and regional integration, are changing the value proposition of hydropower in development [47]. New financing models with increasing resources from the private sector requires a broad range of responses: better policies and institutions along with environmental and social governance (safeguards) improvement; improving payments from energy consumers; clarity in regulations for developing and operating hydro plants; and innovative financial structures that support public-private partnerships projects with multiple (public and private) benefits [47] along with improvement of negotiation capacity with hydropower developers. True least-cost economic planning and realistic demand forecast practices must become common practice among power sector planners [10].

To achieve sustainable development for future hydropower development strengthening of integrated water resources planning and management in river basins is needed in Lao PDR. Issues of balancing goals (social, economic and environmental) and of transparency and participation in planning are also important. Public participation will be a challenge for Lao PDR. There is need for more effective consultation and participation of other stakeholders including local communities in the hydropower planning system to take more effectively social and environmental issues into account.

Lao PDR can draw on the lessons that are emerging from the Nam Theun 2 project. The preparation of it has paved the way for more participatory, transparent and improved hydropower developments. These lessons can be evaluated and replicated in future projects so the best social and environmental programs are put in place in order to effectively manage impacts. The role of Mekong River Commission (MRC) as an institution that can liaise and coordinate between the varying interests of all the countries is vital in sustainable hydropower development in the Mekong basin and it needs to be strengthened. By strengthening of the role of the MRC it can more vigorously exercise its role of helping Mekong countries cooperate and promote sustainable development of its water as it takes its Initiative on Sustainable Hydropower (ISH) [32]. Also, recently the Asian Development Bank, MRC and World Wide Fund for Nature started formulating a joint project on Environmental Considerations for Sustainable Hydropower Development (ECSHD) which aims at developing a sustainability assessment tool for hydropower development that can be integrated into existing planning procedures and processes and move the input of sustainability considerations to earlier stages of the development cycle [8]. 


\section{References}

[1] ADB, The Economics of Climate Change in Southeast Asia: A Regional Review, Asian Development Bank: Manila, 2009.

[2] ADB, Understanding and Responding to Climate Change in Developing Asia, Asian Development Bank: Manila, 2009.

[3] ADB, Asian Water Development Outlook 2007, Asian Development Bank and Asia-Pacific Water Forum: Manila and Tokyo, 2007.

[4] ADB, Reality check of the WCD guidelines. A case study for the Nam Theun 2 hydro-electric project in Lao PDR. Workshop to Discuss the World Commission on Dams Report Dams and Development, Asian Development Bank: Manila, 2001.

[5] ADB, Environments in Transition. Cambodia, Lao PDR, Thailand, Viet Nam, Asian Development Bank: Manila, pp. 4-5, 2000.

[6] Bestari, N., Mongcopa, C., Samson, J. \& Ward, K., Lao PDR: Governance Issues in Agriculture and Natural Resources. A Case Study from the 2005 Sector Assistance Program Evaluation for the Agriculture and Natural Resources Sector in the Lao People's Democratic Republic, Asian Development Bank: Manila, pp. 8, 2006.

[7] Birch, A., Benchmarking National Water Sector Capacity in the Lower Mekong Basin Countries, Discussion Paper, World Bank-ADB Mekong Water Resources Review, pp. 10-11, 2005.

[8] Bird, J., Goichot, M., Makin, I., Moua, K. \& Perera, P., Environmental consideration for sustainable hydropower development in the Mekong region - a joint ADB, MRC and WWF initiative. Yangtze Symposium, pp. 4-6, 2008.

[9] Biswas, A., Integrated water resources management: a reassessment. A Water Forum contribution. Water International, 29(2), pp. 248-256, 2004.

[10] Callander, T., Environmental Impacts of Trade Liberalization in the Hydropower, Mining and Construction Materials Sectors, Lao PDR, Environment Assessment Project (RTEA) - Background Research Paper, International Institute for Sustainable Development (IISD), pp. 1-11, 2007.

[11] Department of Energy Promotion and Development (EPD). Powering Progress. Web Site, Vientiane, www.poweringprogress.org/

[12] Electricité du Laos (EDL), Draft Power Development Plan (2007-16), System Planning Office, Technical Development Committee, Ministry of Energy and Mines, Vientiane, pp. 26-27, 2008.

[13] Environment Protection Fund, www.laoepf.org.la/

[14] Foran, T. \& Greacen, C., Towards More Sustainable Energy Futures for the Mekong Region: Policy Options for Development Donors, pp. 3-5, 2007, Online.

www.palangthai.org/docs/TowardsMoreSustainableEnergyFuturesforMeko ng.pdf

[15] FREPLA2020 Project. Summary of expert workshop. Future Resource and Economy Policies in Lao PDR till 2020 First Expert Workshop, Vientiane. 
The Ministry of Energy and Mines (MEM), The Finland Future Research Centre (FFRC), 2009.

[16] Ganoulis, J., Risk Analysis of Water Pollution, Wiley-VCH Verlag GmbH \& Co. KGaA: Weinheim, pp. 40-200, 2009.

[17] Gerbens-Leenes, W., The hidden water consumption; virtual water. HENVI Science Day 2009: Water Use and Climate Change, 2009, Helsinki University.

[18] Global Water Partnership (GWP), Catalyzing Change: A Handbook for Developing Integrated Water Resources Management (IWRM) and Water Efficiency Strategies, pp. 7, 2005.

[19] Greacen, C. \& Palettu, A., Electricity sector planning and hydropower. Democratizing Water Governance in the Mekong Region, eds. L. Lebel, J. Dore, R. Daniel \& Y.S. Koma, Mekong Press: Bangkok, pp. 94-123, 2007.

[20] Gürbütz, A., The role of hydropower in sustainable development. European Water, 13(14), pp. 64, 2006.

[21] Harrison, G. \& Whittington, H., Impact of climatic change on hydropower investment. Hydropower in the New Millenium, eds. B. Hanningsvåg, G. Midttomme, K. Repp, K. Vaskinn \& T. Westeren, Swets \& Zweitinger, Lisse, pp. 257-260, 2001.

[22] Harremoës, P., Gee, D., MacGarvin, M., Stirling, A., Keys, J., Wynne, B. \& Guedes Vaz, S., Late Lessons from Early Warnings: The Precautionary Principle 1896-2000, Environmental issue report No 22, European Environment Agency, Luxembourg: Office for Official Publications of the European Communities, EEA: Copenhagen, 2001.

[23] Hydropower and Climate Change; World Commission on Dams, WCD Press Releases \& Announcements, Online. www.dams.org/news_events /press333.htm

[24] Hydropower News; Department of Energy Promotion and Development (EPD), Powering Progress, Online. www.poweringprogress.org/index.php? option $=$ com_content\&view=article $\&$ id=196:22-february-2008-investorsurged-to-comply-with-lao-hydropower-standards\&catid=86:hydropowerin-the-media\&Itemid $=50$

[25] International Hydropower Association (IHA), Sustainability Guidelines, 2004, Online.www.hydropower.org/downloads/IHA\%20Sustainability\%20 Guidelines_Feb04.pdf

[26] International Hydropower Association (IHA), The Role of Hydropower in Sustainable Development, 2003, Online. www.hydropower.org/downloads /RoleOfHydropowerInSustDev_IHA\%20White\%20Paper.pdf

[27] Jusi, S., Asian Development Bank and the case study of Theun-Hinboun hydropower project in Lao PDR. Water Policy, 8(5), pp. 371-394, 2006.

[28] Lehni, M., Eco-Efficiency; Creating More Value with Less Impact, World Business Council for Sustainable Development: Geneva, 2000.

[29] Maunsell Limited \& Lahmeyer GmbH, Power System Development Plan for Lao PDR (PSDP), Final Report, Volume A: Main Report, New Zealand, pp. 1-98, 2004. 
[30] McCully, P. \& Wong, S., Powering a sustainable future: the role of large hydropower in sustainable development. UN Symposium on Hydropower and Sustainable Development, pp. 1, 2004, Online. www.internationalrivers.org/files/irnbei.pdf

[31] Mekong River Commission (MRC), Mekong River Commission Annual Report, Lao People's Democratic Republic, Vientiane, pp. 29, 2007.

[32] Mekong River Commission (MRC). The MRC Initiative on Sustainable Hydropower (ISH) Web Site, www.mrcmekong.org/ISH/ISH.htm

[33] Messerli, P., Heinimann, A., Epprecht, M., Phonesaly, S., Thiraka, C. \& Minot, N., (eds). 2008: Socio-Economic Atlas of the Lao PDR - an Analysis based on the 2005 Population and Housing Census. Swiss National Center of Competence in Research (NCCR) North-South, University of Bern, Bern and Vientiane: Geographica Bernensia, pp. 124, 2008.

[34] Nam Theun 2 WMPA homepage, www.nt2wmpa.gov.la/

[35] National Growth and Poverty Eradication Strategy 